\title{
Effect of Mulching on Soil Temperature and Moisture Regime on Emergence, Growth and Yield of White Yam in a Tropical Wet-and-Dry Climate
}

\author{
Eruola A. O $^{1, *}$, Bello N. $\mathbf{J}^{1}$, Ufoegbune G. ${ }^{1}$, Makinde A. $A^{2}$ \\ ${ }^{1}$ University of Agriculture, Abeokuta, Nigeria \\ ${ }^{2}$ National Horticultural Research Institute, Nigeria
}

\begin{abstract}
An on-farm yam experiment was conducted to study the effect of mulching on soil temperature and moisture regime on white yam (Dioscorea rotundata) growth and yield in Abeokuta, South-western Nigeria. Three mulching options (grass mulched, polythene mulched and unmulched) was selected and related to crop growth and yield. Grass mulch significantly $(\mathrm{P}<0.05)$ lowered maximum soil temperature by $1-2^{\circ} \mathrm{C}$ at $15 \mathrm{~cm}$ depth during the thermal critical period (January - March). This led to higher rate of emergence which accounted for 28 and $46 \%$ to the polythene mulch and the unmulched plots respectively. Furthermore, grass mulch had tuber yield of about 4-6 tonnes ha-1 season-1 greater than the polythene mulch and the unmulched plots. Irrespective of mulching materials, it was found that mulching significantly $(\mathrm{P}<$ 0.05 ) increased tuber yield by about 6-8 tonnes ha-1 season-1 than the unmulched. The effect of grass mulch over nylon mulch on yam performance in the study was also discussed.
\end{abstract}

Keywords Dioscorea Rotundata, Mulch, Temperature, Evaporation

\section{Introduction}

Crop production in the tropics as in other parts of the world is sensitive to environmental factors[1]. Climatic factor appeared to be more marked both in terms of its variation over space and time[2]. The major climatic parameters involved in yam production are rainfall, temperature, light, and photoperiod[3,4]. However, moisture and temperature remains the most critical agro-meteorological factor for crop production in the tropics[5]. The occurrence of wet- season- dry spells which may last for a few days to more than three weeks is another serious limiting factor to agricultural management in South Western Nigeria. Incidence of wet season dry spells particularly during the full vegetative stage when evaporative demand is high can lead to retardation of yield formation. The damage is more severe for field crops with shallow root system[6]. However, for location with good soil moisture retention the plants may manage to utilize soil moisture reserve contained in the pores of the soil, or upon the very limited reserve contained in its own tissue during dry spells between rains. Crop may also adopt physiologically or behaviorally to prevent temporary depletion of the stored tissue moisture in other to prevent

* Corresponding author:

bumeruola@yahoo.com (Eruola A. O)

Published online at http://journal.sapub.org/ijaf

Copyright (C) 2012 Scientific \& Academic Publishing. All Rights Reserved impairment of normal physiological function that may cause irreversible damage and plant death, more so that yam is highly susceptible to dry spells that occur during the onset of the rains and particularly before the rain has fully established. Therefore, since yam is planted between the period extending from around the cessation of the rains in a given year to the time of onset in the succeeding year, it implies therefore that as soon as germination starts, soil moisture become critical, hence the need for efficient soil moisture conservation strategy in other to optimize soil physical condition affecting the crop yield. Various techniques used by traditional farmers in modifying the on- farm microclimate and efficiency of such techniques in West Africa have been studied and reported[7-11].[12] reported that mulching is very important in yam cultivation. The beneficial effects of mulching on soil moisture and temperature, and growth and yield have been reported by[7,13,9][10].[14] reported that majority of the traditional yam farmers in West Africa use different mulching materials for yam cultivation. These materials range from dry grass, palm front to wood shaving. Of recent however, the[12] and some less conservative farmers were already using polythene plastic mulch in production of seed yam. However, research into the use of polythene plastic mulch in yam production is not widespread in Nigeria. This paper is an on-farm study and reports of changes in soil temperature and moisture regime and yam growth and yields that result when different types of mulch are applied. 


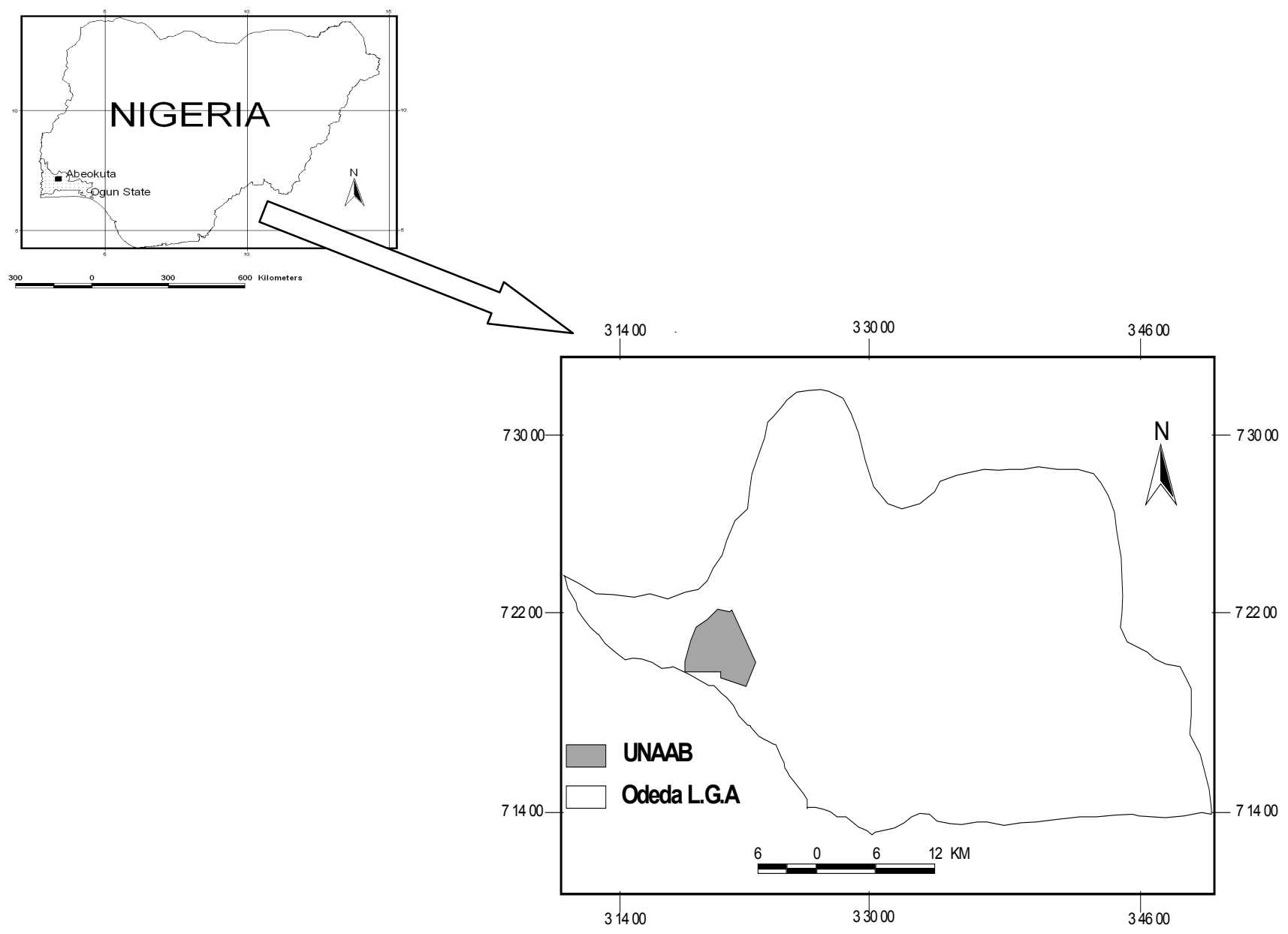

Figure 1. Location of University of Agriculture, Abeokuta within Odeda Local Government Area in Ogun State, Southwestern Nigeria

\section{Materials and Methods}

\subsection{Description of Study Area}

The research was conducted at the Teaching and Research farm of University of Agriculture along Alabata road, Abeokuta $\left(7^{\circ} 15^{\prime} \mathrm{N}, 3^{\circ} 25^{\prime} \mathrm{E}\right)$ in Odeda Local Government Area of Ogun State, South Western Nigeria (fig. 1) during the 2007 and 2008 cropping seasons. The study area is characterized by a tropical climate with distinct wet and dry seasons with bimodal rainfall pattern and mean annual air temperature of about $30^{\circ} \mathrm{C}$. The actual rainfall totals during the 2007 and 2008 cropping season were 1177.2 and $1201.6 \mathrm{~mm}$, respectively. The region is characterized by relatively high temperature with mean annual air temperature being about $30^{\circ} \mathrm{C}$.

The soil at the experimental site was categorized as a well-drained tropical ferruginous soil. The A horizon of the soil is an Oxic Paleudulf of the Iwo series with $83 \%$ sand, $5 \%$ silt and $12 \%$ clay with a pH of 6 considered tolerable by yam cultivation[15].

\subsection{Experimental Design and Field Measurement}

The experimental site, comprised of a piece of land $(30 \mathrm{x}$ $60 \mathrm{~m}^{2}$ ) had previously carried beans and groundnut intercrop but had been fallowed for over 3 years (from 2004-2006). The site was cleared manually using cutlass in November 2006, in preparation for the 2007 cropping following the popular practice by the farmers in the study area. This period marks the preparatory period for the cultivation of early yam planting in the study area. Yam mounds were made manually using African hoe during the two experimental years. The mounds were of height $60 \mathrm{~cm}$ and spaced $1.5 \times 1.5 \mathrm{~m}^{2}$ a walk way of $1 \mathrm{~m}$ between adjacent row. The mound tillage system was selected for the study not only because it is the most widely use method in the study area, but also because it improves the soil aeration and hydrothermal conditions for crops emergence, root development, crop growth and yield[8].Three local white yam, Dioscorea rotundata cultivars (Efuru, ' $\mathrm{A}_{1}$; Ise-osi ' $\mathrm{A}_{2}$; and Oniyere ' $\mathrm{A}_{3}$ ) were used. The choice of selection was due to the fact that the cultivars were the most important edible yams widely grown by farmers in the University's extension villages around the study area. Two mulch materials namely; grass mulch $\left(\mathrm{M}_{1}\right)$ and Polythene nylon $\left(\mathrm{M}_{2}\right)$ were used. About $40 \mathrm{~cm}$ diameter of each mound was covered with dry grass mulch and 
polythene nylon of an average size of $70 \times 50 \mathrm{~cm}^{2}$ was used. The polythene nylon was perforated and has the side covering the mound as black surface and white surface facing the atmosphere. This was adopted in other to regulate the soil temperature. The black surface is to conserve the Long Wave Radiation while the white surface facing up is to reflect excessive Short Wave Radiation. However, mulching was done after planting usually between 6.30-7.30 am when radiation intensity was nil (in other words before sunrises, when the Cambell Stokes Sunshine recorder was unable to receive enough radiation to burn the Sunshine recording card). In addition to the mulched plot, an un-mulch treatment was included in the experiment which served as control (C). In other to achieve a proper sprouting and aeration of setts and effective roots development, the mulching materials were removed from mounds during the humid period. This period coincided with the early tuber formation stage of yam. This period according to[15] is the time when most traditional farmers in West Africa normally remove mulch materials. According to his work, it revealed that if the mulch materials are not removed during the tuber formation stage, it will prevent the infiltration of rainwater to encourage good tuberization.

During each of the phenological stages, daily observation of air and soil temperature $\left({ }^{\circ} \mathrm{C}\right)$ at 15 and $25 \mathrm{~cm}$ depth and rainfall $(\mathrm{mm})$ were made at meteorological enclosure adjacent to the experimental field. Phenological crop growth parameter and yield characters were also measured. Data collected were subjected to analysis of variance (ANOVA) using GenStat Release 7.2 statistical software (Discovery Edition 3) to evaluate the effects of "mulching and mulching materials". The significant difference of treatment means were determined using least significance difference (LSD) $5 \%$ level of probability[16].

\section{Results and Discussion}
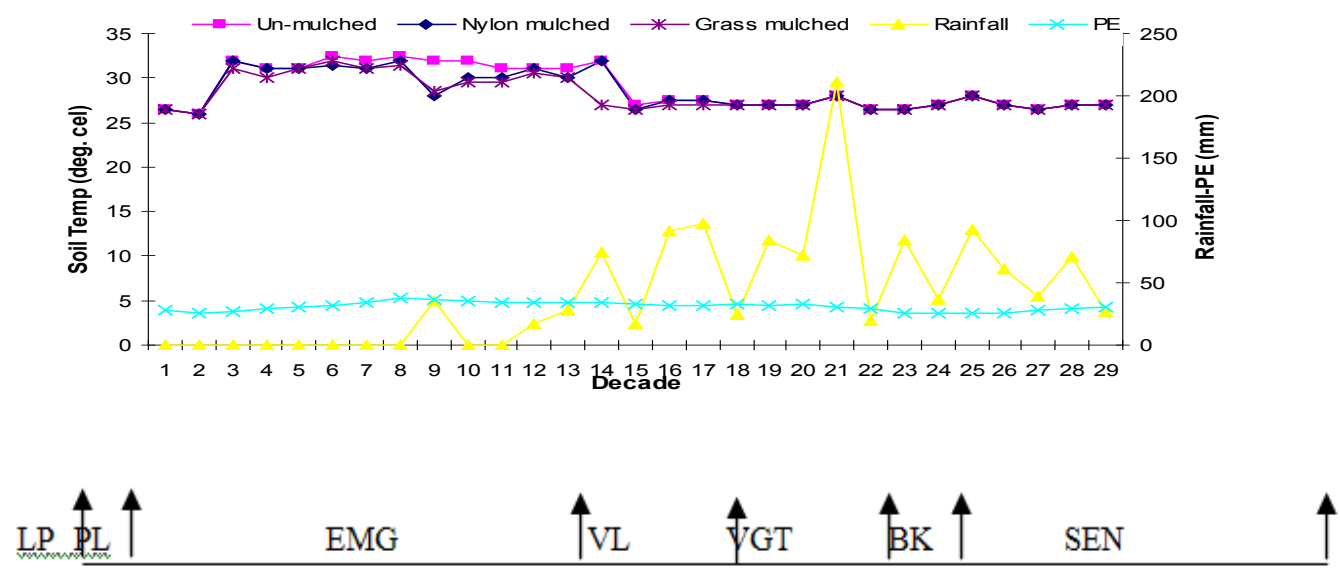

\section{LEGEND}

$\mathrm{LP}=$ Land preparation, $\mathrm{EMG}=$ Emergence, $\mathrm{VL}=$ Vine elongation, $\mathrm{VGT}=$ Vegetative, $\mathrm{BK}=$ Bulking $\mathrm{SEN}=$ Senescence.

Figure 2. The relationship between rainfall-potential evapotranspiration and soil temperature under different mulching materials measured at $15 \mathrm{~cm}$ depth at the phenological stages of white yam in Abeokuta in 2007 


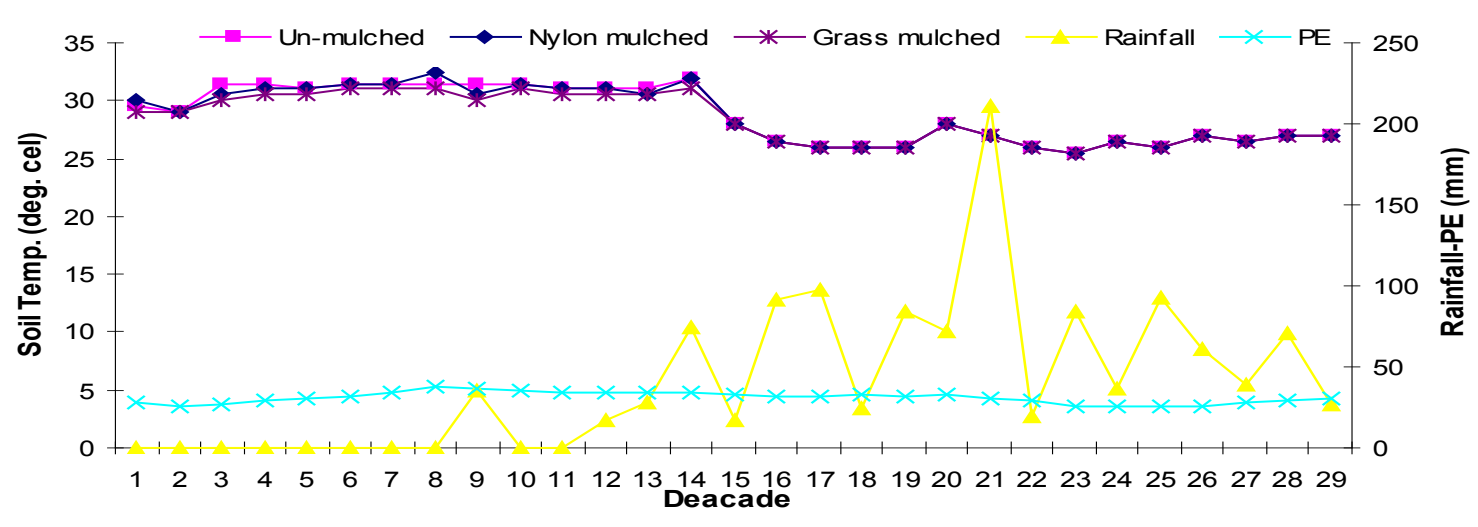

LP PL $_{\mathrm{L}} \uparrow$

EMG

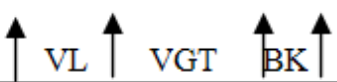

SEN

Figure 3. The relationship between rainfall-potential evapo-transpiration and soil temperature under different mulching materials measured at $25 \mathrm{~cm}$ depth at the phenological stages of white yam in Abeokuta in 2007
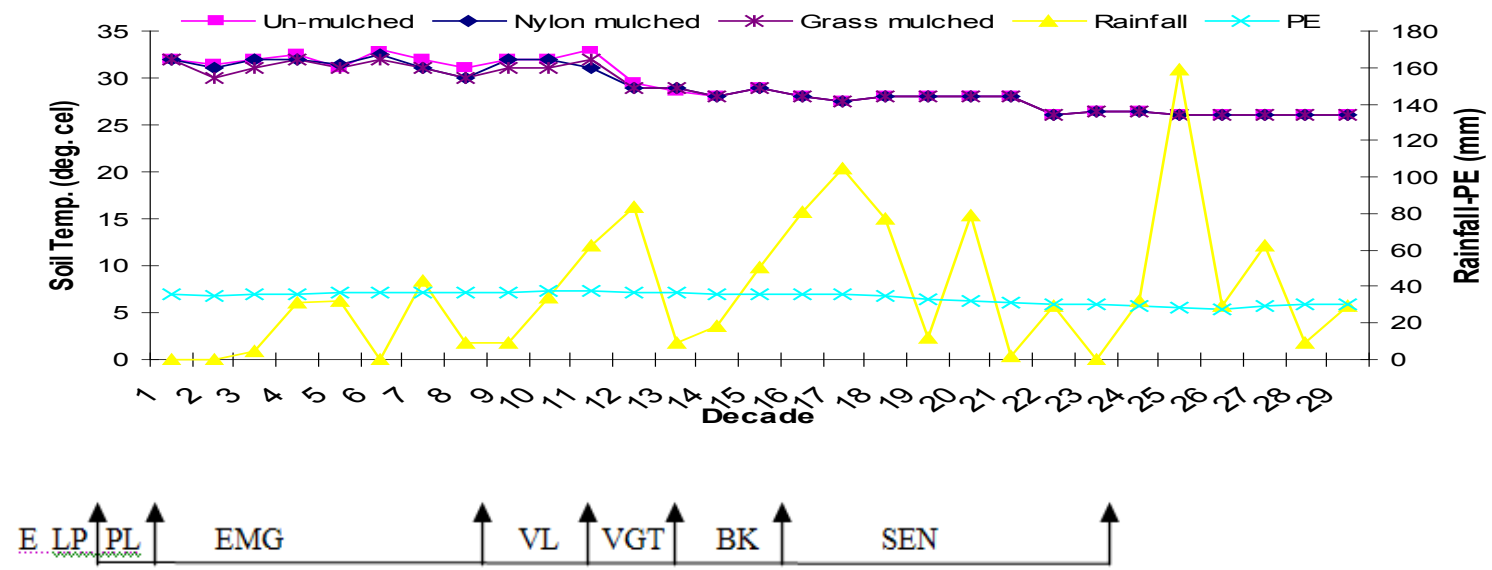

Figure 4. The relationship between rainfall-potential evapotranspiration and soil temperature under different mulching materials measured at $15 \mathrm{~cm}$ depth at the phenological stages of white yam in Abeokuta in 2008
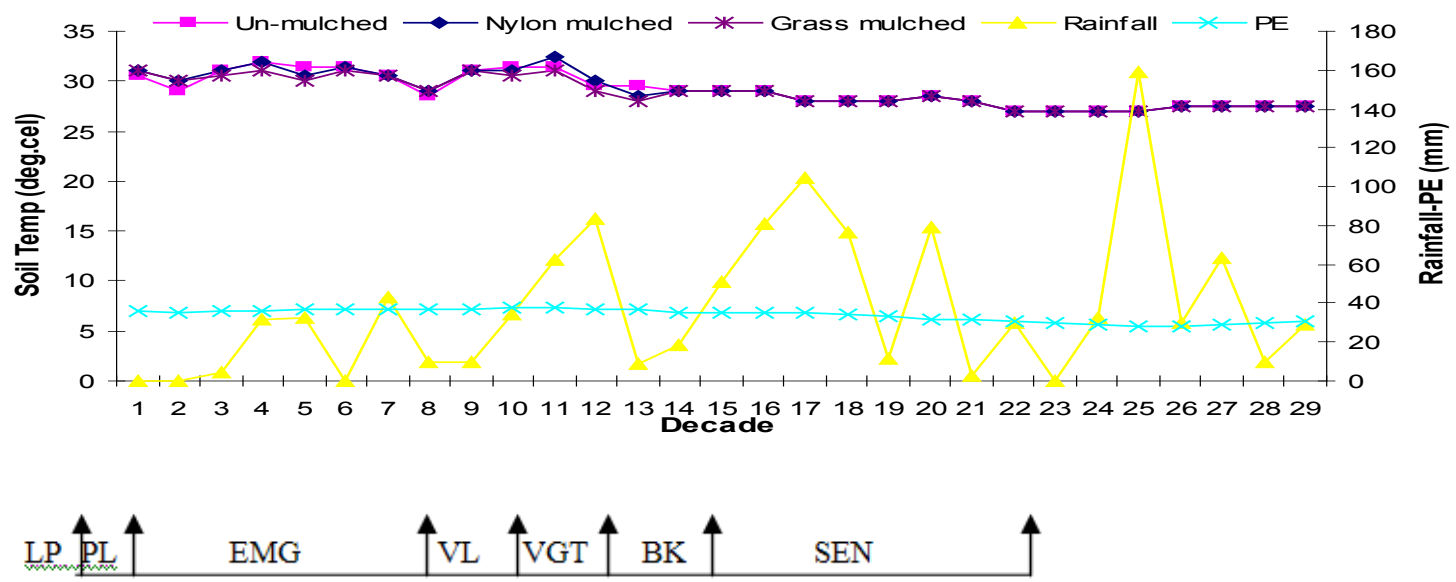

Figure 5. The relationship between rainfall-potential evapo-transpiration and soil temperature under different mulching materials measured at $25 \mathrm{~cm}$ depth at the phenological stages of white yam in Abeokuta in 2008

However, for 2008 as observed from fig. 4 and 5. The soil temperature ranges from 26 to $33 \mathrm{oC}$ for $15 \mathrm{~cm}$ depth and 27 $32.5 \mathrm{oC}$ for $25 \mathrm{~cm}$ depth all through the cropping seasons although the difference in soil temperature at $0-15 \mathrm{~cm}$ depth under the different mulching methods were noticed at the arid periods between the 1st to 12 th decade. The similar soil temperature experienced during the humid period between 13th to 29th decade were as a result of the removal of all the mulches at the beginning of the humid period at the 13th decade for 2008. 
The soil temperature range for 2008 cropping season was lowest at between the 1st and 13th decades under grass mulch, followed by nylon then the un-mulched, this period coincided with the planting all through to early vine elongation period. Of these 13 decades, the rainfall was greater than

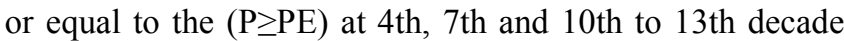
(emergence and vine elongation periods). At these periods, soil temperature values were highest for the un-mulched soil as a result of infiltration of water emitted the high long wave radiation from the soil. Furthermore, it was obvious that the soil temperature were high all through the 13 decades for the un-mulched soil, and that for the periods where $\mathrm{P} \leq \mathrm{PE}$ (i.e the remaining 9 decades), the soil temperature values for the un-mulched and the nylon mulched soil were closely related. The may be due to the fact that nylon mulch top white reflected short wave solar energy and the black bottom conserved the long wave radiation from the soil. The grass mulched plot soil at this period has an average of $31^{\circ} \mathrm{C}$ Similar soil temperature was observed as from 14-29 decade during the humid period when the mulches were removed at the temperature range of $26-28^{\circ} \mathrm{C}$.

When soil temperature was compared at 15 and $25 \mathrm{~cm}$ depth under different mulching method and mulching materials during the 2007 cropping system, it was observed that the soil temperature under the various mulching materials at $15 \mathrm{~cm}$ depth were lower than the $25 \mathrm{~cm}$ depth for $2007 \mathrm{ex}-$ perimental years. The un-mulched plot has an average soil temperature of $30.3^{\circ} \mathrm{C}$, nylon with $29.6^{\circ} \mathrm{C}$ and grass with $29.0^{\circ} \mathrm{C}$ and $30.3^{\circ} \mathrm{C}$ for un-mulch, nylon with $30.2^{\circ} \mathrm{C}$ and grass with $29.8^{\circ} \mathrm{C}$ before the mulches were removed for the $15 \mathrm{~cm}$ and $25 \mathrm{~cm}$ depth respectively at 2007 planting season. This implied that the soil temperature under the various mulching materials at $15 \mathrm{~cm}$ depth were about $1.0{ }^{\circ} \mathrm{C}$ lower than the $25 \mathrm{~cm}$ depth for 2007 experimental years while for 2008 experimental years, the un-mulched plot has an average soil temperature of $31.5^{\circ} \mathrm{C}, 31.2^{\circ} \mathrm{C}$ for nylon mulch and $31.0{ }^{\circ} \mathrm{C}$ for grass and $30.5^{\circ} \mathrm{C}$ for un-mulched, nylon with $30.7^{\circ} \mathrm{C}$ and grass with $30.2^{\circ} \mathrm{C}$ for 15 and $25 \mathrm{~cm}$ depth at the 2008. This implied that the soil temperature under the various mulching materials at $15 \mathrm{~cm}$ depth were about $1.0^{\circ} \mathrm{C}$ higher than the $25 \mathrm{~cm}$ depth for 2008 experimental years. The higher soil temperature $15 \mathrm{~cm}$ than $25 \mathrm{~cm}$ depth agreed with[17] and[15].

The effect of mulching and mulching materials on the phenological crop growth of yam was similar in both experimental years. Generally, the yam planted under mulched plot were significantly higher in emergence rate, vine length, number of stem branches, number of leaves and LAI of yam than for un-mulched plot (Tables $1 \& 2$ ). Irrespective of mulching materials, it was found that mulching significantly $(\mathrm{P}<0.05)$ increased emergence rate of yam by $46 \%$ and tuber yield by about 6-8 tonnes ha-1 season-1 than the unmulched. This finding agreed with previous report that the emergence and growth rate of yam seedling were observed to be significantly higher in mulched plots than the un-mulched plot by[13][18]. Increased emergence and more rapid development of setts in mulched yams could be attributed to an increase in soil moisture content and the consequent modification of soil temperature under mulched $\operatorname{plot}[17][7][13][9][10]$. Furthermore, there was significant difference in these parameters with different type of mulching material used for the two experimental years. The grass mulched significantly improved the growth, development and yield of yam than the perforated white surface up and black surface facing down polythene nylon. The grass mulch emergence rate was $28 \%$ higher than the polythene mulch. Furthermore, grass mulch had tuber yield of about 4-6 tonnes ha-1 season-1 greater than the polythene mulch and the unmulched plots. The beneficial effects of grass mulch on yam growth could be attributed to the nutrients released by decomposing mulch[7][13], and its physical effect on the possible reduction of nutrient losses by surface erosion and leaching. Furthermore, the beneficial effect of polythene nylon was also discussed by[19]. He reported that using polythene nylon mulch will considerably improve the production of yam and in particular the seed yam by checking the weed growth. A survey carried out in Nigeria showed tremendous increase in the adoption of the use of polythene nylon, hence there is a clear.

Table 1. Effect of mulching and mulching materials on growth of three white yams grown at Abeokuta during 2007 cropping season

\begin{tabular}{|c|c|c|c|c|c|c|c|c|c|c|}
\hline Factor & $\begin{array}{c}\text { Emerg } \\
\%\end{array}$ & $\begin{array}{c}\text { Vine length } \\
(\mathrm{cm})\end{array}$ & $\begin{array}{c}\text { No. } \\
\text { branch }\end{array}$ & No. leaves & No roots & $\begin{array}{c}\text { Vine } \varnothing \\
(\mathrm{cm})\end{array}$ & $\begin{array}{c}\text { Branch } \\
\text { length(cm })\end{array}$ & $\begin{array}{c}\text { Root } \\
\text { length } \\
(\mathrm{cm})\end{array}$ & \begin{tabular}{c} 
LAI \\
\multicolumn{7}{|c|}{ Mulching material }
\end{tabular} \\
\hline $\mathrm{C}$ & $14.8 \pm 2.71$ & $31.1 \pm 15.54$ & $14.3 \pm 1.41$ & $239.6 \pm 42.56$ & $20.2 \pm 2.90$ & $1.272 \pm 0.08$ & $58.8 \pm 6.82$ & $23.8 \pm 3.15$ & $0.044 \pm 0.02$ \\
\hline $\mathrm{M} 1$ & $68.4 \pm 5.33$ & $150.4 \pm 30.21$ & $24.3 \pm 2.98$ & $757.2 \pm 125.68$ & $23.7 \pm 2.97$ & $1.447 \pm 0.05$ & $74.9 \pm 6.34$ & $32.2 \pm 2.84$ & $1.650 \pm 0.42$ \\
\hline $\mathrm{M} 2$ & $46.2 \pm 5.20$ & $47.7 \pm 16.22$ & $16.9 \pm 2.43$ & $455.2 \pm 117.99$ & $16.9 \pm 1.80$ & $1.444 \pm 0.05$ & $58.7 \pm 7.21$ & $28.9 \pm 2.53$ & $0.611 \pm 0.21$ \\
\hline $\mathrm{P}$ & $<0.001^{*}$ & $<0.001^{*}$ & $0.010^{*}$ & $<0.001^{*}$ & 0.190 & $0.049^{* *}$ & 0.124 & 0.079 & $<0.001^{*}$ \\
\hline
\end{tabular}

*Significant at $\mathrm{P}<0.01 * *$ Significant at $\mathrm{P}<0.0$ 
Eruola A. O et al.: Effect of Mulching on Soil Temperature and Moisture Regime on Emergence, Growth and Yield of White Yam in a Tropical Wet-and-Dry Climate

Table 2. Effect of mulching and mulching materials on growth of three white yams grown at Abeokuta during 2008 cropping season

\begin{tabular}{|c|c|c|c|c|c|c|c|c|c|c|}
\hline Factor & $\begin{array}{c}\text { Emerg } \\
\%\end{array}$ & $\begin{array}{c}\text { Vine } \\
\text { length } \\
(\mathrm{cm})\end{array}$ & $\begin{array}{c}\text { No. } \\
\text { branch }\end{array}$ & No. leaves & No roots & $\begin{array}{c}\text { Vine } \varnothing \\
(\mathrm{cm})\end{array}$ & $\begin{array}{c}\text { Branch } \\
\text { length }(\mathrm{cm})\end{array}$ & $\begin{array}{c}\text { Root } \\
\text { length } \\
(\mathrm{cm})\end{array}$ & $\begin{array}{c}\text { LAI } \\
\text { Mulching material }\end{array}$ \\
\hline $\mathrm{C}$ & $51.6 \pm 3.81$ & $271 \pm 34.29$ & $12.6 \pm 1.13$ & $255.0 \pm 16.7$ & $23.8 \pm 4.22$ & $1.261 \pm 0.07$ & $68.1 \pm 7.09$ & $28.9 \pm 3.22$ & $0.339 \pm 0.06$ \\
\hline $\mathrm{M}_{1}$ & $94.0 \pm 1.56$ & $476 \pm 37.0$ & $32.4 \pm 3.72$ & $680.3 \pm 65.80$ & $27.8 \pm 3.13$ & $1.508 \pm 0.06$ & $101.1 \pm 12.67$ & $34.7 \pm 2.73$ & $1.706 \pm 0.17$ \\
\hline $\mathrm{M}_{2}$ & $68.1 \pm 4.30$ & $360 \pm 41.91$ & $21.7 \pm 3.20$ & $415.8 \pm 42.49$ & $24.8 \pm 1.98$ & $1.450 \pm 0.06$ & $65.9 \pm 7.60$ & $32.0 \pm 2.87$ & $0.751 \pm 0.10$ \\
\hline $\mathrm{P}$ & $<0.001 *$ & $<0.001 *$ & $<0.01 *$ & $<0.001 *$ & 0.700 & $0.019 * *$ & $0.023 * *$ & 0.408 & $<0.001 * *$ \\
\hline
\end{tabular}

*Significant at $\mathrm{P}<0.01 \quad * *$ Significant at $\mathrm{P}<0.05$

Table 3. Effect of mulching and mulching materials on yield and yield characteristic of three white yams grown at Abeokuta during 2007 cropping season

\begin{tabular}{|c|c|c|c|c|c|c|}
\hline \multirow{2}{*}{ Factor } & $\begin{array}{c}\text { Tuber length } \\
(\mathrm{cm})\end{array}$ & $\begin{array}{c}\text { Tuber diameter } \\
(\mathrm{cm})\end{array}$ & $\begin{array}{c}\text { Tuber weight } \\
(\mathrm{kg})\end{array}$ & \multicolumn{2}{c|}{ No of tuber } & $\begin{array}{c}\text { Harvest yield } \\
\text { ton/ha }\end{array}$ \\
\hline \multicolumn{7}{|c|}{ Mulch material } \\
\hline \multicolumn{7}{|c|}{} \\
\hline $\mathrm{C}$ & $10.60 \pm 3.91$ & $2.89 \pm 1.01$ & $0.84 \pm 0.29$ & $0.556 \pm 0.23$ & $1.11 \pm 0.41$ \\
\hline $\mathrm{M}_{1}$ & $27.7 \pm 2.19$ & $8.30 \pm 0.70$ & $2.37 \pm 0.30$ & $0.972 \pm 0.06$ & $8.74 \pm 1.50$ \\
\hline $\mathrm{M}_{2}$ & $20.8 \pm 4.58$ & $5.14 \pm 1.45$ & $1.56 \pm 0.38$ & $0.556 \pm 0.12$ & $4.35 \pm 1.14$ \\
\hline $\mathrm{P}$ & $<0.001^{*}$ & $<0.001^{*}$ & $<0.001^{*}$ & $<0.028^{* *}$ & $<0.001^{*}$ \\
\hline
\end{tabular}

*Significant at $\mathrm{P}<0.01 \quad * *$ Significant at $\mathrm{P}<0.05$

Table 4. Effect of mulching and mulching materials on yield and yield characteristic of three white yams grown at Abeokuta during the 2008 cropping season

\begin{tabular}{|c|c|c|c|c|c|}
\hline Factor & $\begin{array}{l}\text { Tuber length } \\
(\mathrm{cm})\end{array}$ & $\begin{array}{l}\text { Tuber diameter } \\
(\mathrm{cm})\end{array}$ & $\begin{array}{c}\text { Tuber weight } \\
(\mathrm{kg})\end{array}$ & No of tuber & $\begin{array}{c}\text { Harvest yield } \\
\text { ton/ha }\end{array}$ \\
\hline \multicolumn{6}{|c|}{ Mulch material } \\
\hline $\mathrm{C}$ & $31.8 \pm 2.87$ & $9.52 \pm 0.75$ & $2.54 \pm 0.29$ & $1.078 \pm 0.08$ & $6.24 \pm 0.87$ \\
\hline M1 & $39.1 \pm 1.71$ & $12.36 \pm 0.53$ & $3.97 \pm 0.17$ & $1.150 \pm 0.03$ & $17.59 \pm 0.88$ \\
\hline M2 & $37.6 \pm 1.87$ & $12.08 \pm 0.50$ & $3.52 \pm 0.21$ & $1.144 \pm 0.04$ & $11.28 \pm 0.94$ \\
\hline$P$ & $0.043 * *$ & $<0.001^{*}$ & $<0.001^{*}$ & 0.567 & $<0.001^{*}$ \\
\hline
\end{tabular}

*Significant at $\mathrm{P}<0.01 * *$ Significant at $\mathrm{P}<0.05$.

promise for a future boom in the supply of seed yam in particular[12]. The high rate of emergence associated with mulched treatment must be the basic reason why some traditional farmers in the study area usually mulch their yam immediately after planting[18].

It is interesting to note that there were no significant difference between number of roots, vine diameter and root length of yam planted under mulched and un-mulched plot, and also with different type of mulching material used during the two experimental year.

The effect of mulching and mulching material on the yield and yield components of yam were also similar in both ex- perimental years. Generally, irrespective of variety of white yam planted, the yam planted under mulched plot were significantly higher in tuber length, tuber diameter, tuber weight and yield of yam than for un-mulched plot (Tables $3 \& 4$ ). This finding also agreed with previous report that the yield and yield components of yam were observed to be significantly higher in mulched plots than the un-mulched plot by[13][18][19]. However, the significant reduction in the tuber length, tuber diameter, tuber weight and yield of yam as experienced in the 2007 experimental year as compared to 2008 year could be attributed to the moisture stress that marked the arid period of the 2007 year, thereby causing 
disparity in yam setts sprouting in all varieties under all mulched and un-mulched plots. Furthermore, there was significant difference in these parameters with different type of mulching material used for the two experimental years. The grass mulched plots were observed to be significantly higher than the perforated white surface up and black surface facing down polythene nylon. The beneficial effects of mulch on tuber yield particularly during the 2008 experimental year were probably due to favorable hydrothermal regimes of the soil for emergence and early development of yam plants. The mulch was also observed to increase the growth and tuber yield of yams possibly by reducing nutrient losses through controlling runoff and leaching in the raining season. The high yield as experienced in the grass mulch was also attributed partly to the possible influence of decomposed mulch material on increase in soil nutrient status and availability since the grass mulch is known to contain some element of Nitrogen, magnesium, calcium, phosphorus and potassium[19], and these nutrients, particularly $\mathrm{P}, \mathrm{N}$ and $\mathrm{K}$ are important in the growth and bulking of yam tubers, and consequently in the tuber yield[20]. Since fertilizer was not used in the study, the higher growth and tuber yield observed in the grass mulched plots compared to both the perforated white surface up and black surface facing down polythene nylon mulch and the un-mulched plots in the two experimental years was attributed to the effect of decomposed mulch on the nutrient content and in ameliorating soil physical conditions.

It is also interesting to note that there was no significant difference between number of tuber of yam planted under mulched and un-mulched plot and with different type of mulching material used during the two experimental year.

\section{Conclusions and Recommendations}

From this study, it is obvious that mulching significantly improves soil temperature, the emergence and development of yam setts and increased tuber yield. The physical effect of the mulch, through reducing nutrient losses by runoff, erosion and leaching and decreasing maximum soil temperature and conserving moisture may have increased growth and tuber yield as compared to un-mulch. The result of the study further revealed that the type of mulching material used also influences the emergence, development and yield of yam. The grass mulch has significantly lower soil temperature and produced higher yield than the polythene mulch. One chemical effect of grass mulch over nylon mulch on yam performance in the study might be the release of nutrients, particularly the nitrogen and phosphorous from decomposed grass while on the other hand the polythene mulch is not biodegradable. However, both mulches have the physical effect of reduction of nutrient losses by surface erosion and leaching and also checks weed growth.

\section{REFERENCES}

[1] Obiokoro, O.G. 2005. Agrometeorology. Onitsha: Dunkwu Publishers. pp. 24-30

[2] Vernier P, Dansi P (2000). Participatory assessment and farmers' knowledge on yam varieties (D. rotunda and D. cayenensis) in Benin. Paper presented at the ISTRC 2000 symposium, Tsukuba, Ibaraki, Japan, Sept. 10-16 2000. pp. $1-17$

[3] Orkwor, G.C and Ekanayake, I.J. 1998. Growth and Development. In: The progress in yam Research. G.C.Orkwor, R. Asiedu and I.J. Ekanayake, eds.IITA, Ibadan, Nigeria. 39-62pp

[4] Ekaputa, U.N. 2004. Agricultural systems. Port Harcourt: UNIK Publishers. pp. 126-134

[5] Krammer, P.J. 1963. Water stress and plant growth. Agronomy Journal, 5: 31-35

[6] Fageria, N.K. 1980. Deficiencia hidrica em arroz de cerrado e resposta ao fosforo. Pesqui. Agropec. Bras. 15: 259-265

[7] Maduakor, H.O., Lal, R., Opara-Nadi, O.A. 1984. Effects of methods of seedbed preparation and mulch on the growth and yield of white yam (Dioscorea rotundata) on an ultisol in south-east Nigeria. Field Crops Res. 9: 119-130

[8] Kutugi, A.D. 2002. Comparative analysis between indigenous and modern tiilage practices in the production of Dioscorea rotundata and Dioscorea cayenensis in the middle belt of Nigeria. Journal agriculture environment 2(1): 53-66

[9] Okoh, C.A. 2004. The effect of mulching on soil physico-chemical properties and the yield of White Yam. Trop. J. Root Tuber Crops 4(2): 24-31

[10] Inyang, E.U. 2005. An evaluation of tillage and storage systems applied by traditional root crop farmers in Cameroon. Agric. Envron. J. 7(2): 15-22

[11] Gbadebor, P.V. 2006. The climate, the soils and the West African traditional farmers. AgroEcosystem Bull. 4: 12-17

[12] International Institute of Tropical Agriculture (IITA). 1995. Yam research at IITA: 1971-1993. IITA Ibadan, Nigeria. 38pp

[13] Olasantan, F.O. 1999. Effect of mulching on soil temperature and moisture regime and emergence, growth and yield of white yam in western Nigeria. Soil and tillage research 50: 215-221

[14] Lai, R. 1987. Soil temperature, soil moisture and maize yield from mulched and un-mulched tropical soil. Plant and Soil. 40: $129-143$

[15] Olasantan, F.O. 2007. Effect of population density and sowing date of pumpkin on soil hydrothermal regime, weed control and crop growth in a yam -pumpkin intercrop. Experimental Agriculture 43: 365-380

[16] Steel, R.G.B. and Torrie, J.H. 1988. Principle and procedures of statistics, M cGraw - Hill Book Co., New York, U.S. 633PP

[17] Lai, R. 1975. Role of mulching techniques in tropical soil and water management. Technical Bulletin, International Institute of Tropical Agriculture, Ibadan, Nigeria. 38pp

[18] Odjugo, P.A.O.2008. The effect of tillage systems and mulching on soil microclimate, growth and yield of yellow 
yam (Doiscorea Cayenensis) in Midwestern Nigeria. African Journal of Biochemistry. 7(24):4500-4507

[19] Hahn, S. K., Osiru, D.S.O., Akoroda, M.O. and Otoo, J.A. 1987. Yam product and its future prospects. Outlook on Agriculture 16(3):105-110
[20] Solubo, R.A. 1972. Studies on white yam (Doiscorea rotundata). II. Change in nutrient with age. Expl. Agriculture 8: 107-115 